УДК 327.8

\title{
CONCEPTUAL PROVISION OF US GLOBAL LEADERSHIP POLICY OF POST-BIPOLAR PERIOD
}

\author{
КОНЦЕПТУАЛЬНЕ ЗАБЕЗПЕЧЕННЯ ПОЛІТИКИ ГЛОБАЛЬНОГО \\ ЛІДЕРСТВА США ПОСТБІПОЛЯРНОЇ ДОБИ
}

\section{КОНЦЕПТУАЛЬНОЕ ОБЕСПЕЧЕНИЕ ПОЛИТИКИ ГЛОБАЛЬНОГО ЛИДЕРСТВА США ПОСТБИПОЛЯРНОЙ ЭПОХИ}

\section{Litvinenko $\mathbf{N}$.}

$\mathrm{PhD}$ (Economics); Associate Professor at the Department of International Information of Institute of International Relations, Taras Shevchenko National University of Kyiv.

\section{Pogorila N.}

Applicant, Department of International Information, Institute of International Relations Taras Shevchenko National University of Kyiv. E-mail: natalia.pogorelaya@gmail.com.

Литвиненко Н. П.

Кандидат економічних наук, доцент кафедри міжнародної інформації Інституту міжнародних відносин Київського національного університету імені Тараса Шевченка.

\section{Погоріла Н. А.}

Здобувач кафедри Міжнародної інформації Інституту міжнародних відносин Київського національного університету імені Тараса Шевченка. E-mail: natalia.pogorelaya@gmail.com.

\section{Литвиненко Н. П}

Кандидат экономических наук, доцент кафедры международной информации Института международных отношений Киевского национального университета имени Тараса Шевченко.

\section{Погорила Н. А.}

Соискатель кафедры Международной информации Института международных отношений Киевского национального университета имени Тараса Шевченко. E-mail: natalia.pogorelaya@gmail.com

Abstract. Article deals with conceptual and theoretical grounds for US global leadership policy in the post-bipolar period. In this context, the strategy of US global leadership during the presidency of Bill Clinton is thoroughly researched. On the conceptual level the existing strategy of US global leadership under President George. W. Bush is being reviewed. The liberal realistic concept of US leadership under presidency of B. Obama found further development. The basic differences in foreign policies between Republican and Democratic US administration post-bipolar era were revealed. It is reported that the US would continue to play a crucial role in world politics and provide conceptual and applied political and security strategies of the United States, which affect foreign policy and constitute an integral part of US geopolitical interests.

Key words: doctrine, strategy, concept, leadership, US, hegemony, post-bipolar international system, foreign policy.

Анотація. Проаналізовано концептуально-теоретичні засади забезпечення політики глобального лідерства США постбіполярної доби. У иъьому контексті поглиблено досліджено стратегію глобального лідерства США за президентства Б. Клінтона. На концептуальному рівні розглянуто наявні стратегї глобального лідерства США за прези- 
дентства Дю. Буша молодшого. Подальшого розвитку набула ліберально-реалістична конщепція лідерства США за президентства Б. Обами. Виявлено основні відмінності у зовнішньополітичних стратегіях між республіканською та демократичною адміністрачією США постбіполярної доби. Зазначається, щчо США й надалі відіграватимуть вирімальну роль у світовій політиці, а концептуальне і прикладне забезпечення політичних i безпекових стратегій США, які впливають на міжнародну політику, є невід 'ємною складовою геополітичних інтересів США.

Ключові слова: доктрина, стратегія, кониепція, лідерство, США, гегемонія, постбіполярна міжнародна система, зовнішня політика.

Аннотация. Проанализированы концептуально-теоретические основы обеспечения политики глобального лидерства США постбиполярной эпохи. В этом контексте углубленно исследовано стратегию глобального лидерства США при президентстве Б. Клинтона. На концептуальном уровне рассмотрень имеющиеся стратегии глобального лидерства США при президентстве Дж. Буша младшего. Дальнейшее развитие получила либерально-реалистичная кониепџия лидерства США при президентстве Обамы. Выявлены основные различия во внешнеполитических стратегиях между республиканской и демократической администрачией США постбиполярной эпохи. Отмечается, что США и в дальнейтем будут играть решаюшую роль в мировой политике, а кониептуальное и прикладное обеспечение политических стратегий и стратегий безопасности США, которые влияют на международную политику, является неотъемлемой составляющей геополитических интересов США.

Ключевые слова: доктрина, стратегия, концепџия, лидерство, США, гегемония, постбиполярная международная система, внешняя политика.

Current problems. Transformation of the Yalta-Potsdam order, which began in the late 1980s. was resulted in the collapse of the bipolar international system in 1991. The unique position of the United States as the sole superpower has opened before them the opportunity to influence the course and essence of international relations in a single-handed way. All the US administrations of the post- bipolar era were guided by several basic principles. They were based on the fact that the USA is a protector, initiator of liberal and religious values. Therefore, the US should deal with authoritarian regimes and spread the neoliberal model of democracy as the universal and the best form. But in the end of Obama's presidency, it became clear that the United States faced with problems related to the preservation of leadership in the world. It caused the discussion that many scientists point out on the existence of the neoliberal model of globalization and democracy crises.

Analysis of recent research and publications revealed actual problems and prospects of implementation of the strategy of US global leadership post-bipolar era. They have been reflected in publications of Ukrainian, Western and Russian specialists and scientists in this field. Among the western school of scientists it is possible to distinguish such researches as $\mathrm{Zb}$. Brzezinski [1], R. Dole, W. G. Hyland [2], R. Kagan [3], Sh. Schwenninger [4], J. White [5] etc.

Scientific achievements of the Ukrainian political science are represented by such scholars as I. D. Dudko [6], D. M. Lakishyk [7], M. V.Ponomarev [8], G. A. Piskorska, I. I. Pohorska, M. M. Ryzhkov [9], M. V. Fesenko [10], S. O. Shergin [11], N. L. Yakovenko [12].

Among the Russian scientists the most noteworthy scientific works are represented by D. Zhilzov [13], A. P. Kabachenko [14], R. S. Mursalov [15], M. A. Troizky [16], A. V. Torkunov [17], T. A. Shakleina [18] and so on.

The aim of the article is to compare and analyze the strategy of US global leadership for the presidency of Bill Clinton, George. W. Bush and Barack Obama. 
The important research results. In the early 1990's. the ruling US administration was the Republican one with President George. W. Bush Sr., whose foreign policy as well as his predecessor's Ronald Reagan, was determined by neoconservative ideologues of US foreign policy. It featured a strong ambition to gain global leadership and a readiness to provide the conditions for this at all costs. Approval of US leadership served as a necessary counterbalance to the expansion of the Soviet Union, which threatened the freedom and security in the world.

However, the collapse of the USSR has not made significant changes to the policy settings of Republicans. In this respect $\mathrm{Zb}$. Brzezinski characterizes the beginning of the new post-bipolar era in the following way: "As a result of the collapse of the rival the United States found themselves in a unique position. They became the first and the only true one global power ... The situation that has arisen put on the Republican Administration three global missions that are not identical to the traditional problems of national security. The success or failure of the United States in their implementation of ambitious plans had to serve as a test of their capability for global leadership against the background of strengthening the national aspirations of the inhabitants of all continents and sudden shifts of geopolitical balance" [19].

The end of the "Cold War", loss of the global enemy and alongside with it the global threat, weakened the position of neoconservatives that came to power in the US in 1993. The Democratic administration of Bill Clinton (1993-2000) has adopted a liberal-conservative conception of global leadership. In this context, the analysis of foreign policy strategy of Clinton administration allows us to make political examination of the US global leadership strategies on the early stage of post-bipolar period. In broad-spectrum, the US strategy under the presidency of B. Clinton was aimed at achieving global leadership based on force and the regulation of international relations involving allies such as the EU and international organizations such as NATO. In general, for the period of the presidential administration of B. Clinton the force regulation or aspiration for hegemony was liberal.

Three National Security Strategies of the United States of 1994, 1995 and 1996 were developed and adopted during B. Clinton's presidency under one and the same name - "The strategy of involvement in international affairs and the spread of democracy in the world". The abovementioned Strategies focused on the security and prosperity of the country by supporting the US status as a major world power, strengthening active leadership of the country abroad as a necessary factor in improving safety, the recovery of the US economy and opening it to the new markets. But the long-term goal of Washington was to build a new world order led by the United States and the leading countries of the world that belong to the Western democracy, with a gradual accession to it by many other countries which share the principles of market economy and other Western values. Thus the main objectives set out in the abovementioned documents are based on the ideas that complement each other and directed to enhance security by means of armed forces effectiveness. Much attention is paid to the ways of promoting the economic growth of the USA and strengthening democracy abroad [20, p. 6, 7].

It should be noted that often the views of representatives of liberal, neoliberal, conservative and neo-conservative directions in the science of international relations coincided concerning the methods of the US ambition implementation towards global leadership and priorities in foreign policy. Namely for these reasons, the official US national security strategies are ideological symbiosis with certain differences between the conceptual views. It is stated that supporters of the Democratic Party had more rhetoric about democracy, collectivism and diplomacy. On the other hand the supporters of the Republican Party often underline a threat to national security and existence of the enemies of the United States. But both Democrats and Republicans were unanimous on the issue of ways to use the US military power to implement their global strategies. It 
was aimed at protecting the US interests that are focused on the transformation of the international system based on the ideas of liberal democracy [21, p. 36].

President Clinton was able to realize ambitious plans to implement the US strategy of global leadership because he had a new vision of the problems of the United States at the turn of the twenty-first century. In the era of globalization and the formation of post-industrial society, the rapid development of information and communication technologies the Clinton administration put emphasis on human capital development, that was accompanied by investments in education and health care. Against this background of all the above mentioned the considerable attention was paid namely to economic development, that allowed steady growth in the US economy. Thus, from 1992-2001 the US GDP grew in more than 1.5 times, from 6 trillion of USD to 10 trillion of USD. An important contribution to the US economic growth made by the Clinton administration turned to be the creation of NAFTA, which created a common market with population of over 400 million of people that are the residents of the USA, Canada and Mexico. These achievements were accompanied by the implementation of the strategy of spreading American values, culture and especially the neo-liberal model of democracy. It allowed to characterize the Clinton administration's foreign policy course as "democratic leadership" with elements of "liberal hegemony" because of the comprehensive control over all international processes, regions and definite states.

George Bush Jr., the third US president (2001-2009), alongside with the Republican Party made significant changes in the US foreign policy, which is meant to support policy of the global US leadership. The new approach is often characterized as a "neoconservative". Abstract ideological foundations of the new administration soon appeared in the US foreign policy, which gradually began to take shape of a new doctrine. The starting point came a few months after the inauguration of George Bush Jr. to the presidency when on the September 11, 2001 a series of terrorist attacks took place. This sorrow event empowered the new Republican administration to declare a "war against terrorism".

Thus, the beginning of the presidency of George Bush Jr. in the United States was marked by the terrorist attacks of September 11, 2001 that dramatically affected the doctrinal dimension of the US foreign policy strategy. In the whole, the "Bush doctrine" was based on a number of documents, among which one can single out the National Strategy of information exchange, National Strategy for combating terrorism, National Security Strategy of the USA in 2002, the National Security Strategy of the USA in 2006, National Strategy for Homeland Security and in the document named "Five years after the September eleventh".

Central place in the conceptual dimension of the strategy of US global leadership under the President of George Bush Jr. takes the concept of the so-called "hard" hegemony. It was implemented by Bush's Republican Administration and was developed by scientists and politicians who represented "the right direction" of traditional conservatism. Among the American scholars of US foreign policy primarily distinguishes scientific refinement of Zb. Brzezinski that justifies the need for American global leadership. In this context it should be especially noted that scientific views of M. McFaul and M. Albright has also became the significant background for traditional conservatism development. Their views could be described as liberal ones with extreme conservative positions. According to this concept, the United States had exclusive rights and the possibility for the formation of a new international order for the American model, according to the Western values, based on existing international political, military and economic organizations that have proved effectiveness and ensured the victory of the West in the Cold War. According to the supporters of this approach, other members of the international community had to adapt themselves to the new system. 
Security Strategy 2002 identifies the main aim of preserving peace by "fighting terrorism and tyranny" [22]. The problem of terrorism as a major threat to the national security had to be solved through "the use of any available weapon in the arsenal - military power, homeland and internal security improvement, enforcement of the law, work of intelligence and other important events to discontinue the financing of terrorist organizations" [23]. The "Bush Doctrine" made a significant emphasis on the military component of the US foreign policy. The main thesis became the one that concerned elimination of threats using preventive operations of military and paramilitary nature, performed either solely by the USA or in coalition with other countries [24, p. 60].

National Security Strategy of the United States of 2006 is often referred to as security strategy in war [25]. Having identical structure with the previous document, the new strategy focused on the global war on terrorism and included aspects such as resolving regional conflicts, strengthening allied formations and overcoming the challenges of globalization. Security Strategy of 2006 contained a report on the results achieved according to the objectives of the previous strategy (2002), and identified the main priorities for the future. In this context it should be mentioned that the military achievements in Iraq and Afghanistan were undoubtedly exaggerated. Thus, among the achievements of the US foreign policy it is worth mentioning the loss of "Al Qaeda's" positions in Afghanistan and the development of democratic system in Iraq. For sure it clearly contradicts to the present-day views on the situation and the US military action in these countries by B. Obama's Administration. In the final part of the 2006 Security Strategy it is stated that "America has faced with significant challenges, but has huge potential and opportunities to deal with them", which once again confirms the belief in the existence of unipolar world led by the US [23].

That same year, in addition to the National Security Strategy of the USA (2006) the National Strategy for combating terrorism was adopted [26]. Under conditions of having war against terrorism the fundamental ground of the new document became "the destruction of the largest network "Al Qaeda" and opposition to the radical ideology that inspires others to join the terrorist movement". Methods to achieve this goal correspond to the methods specified in the National Security Strategy $(2002,2006)$, and also include the fight against proliferation of weapons of mass destruction and the existence of the phenomenon of extremist states. In September 2006, a document called "Five years after the eleventh of September: successes and challenges" was developed. It analyzed the achievements and potential threats that the international community faces in the global war on terrorism [23].

Within the liberal-realist conception of leadership the doctrine of Barack Obama represents notable scientific interest as it analyses the future prospects of the US leadership in the world. According to many analysts Barack Obama rejected the American leadership, an idea that for decades defined the US role in the world and consciously reduced American global commitments. However, against this background declarative rhetoric of Obama is based on thorough conceptual support of foreign policy, including the National Security Strategy of 2010, 2015. Thus Obama's declarative rhetoric indicates that the USA would not abandon the policy of world leadership, and even with the new approaches and available resources the USA would be able to strengthen their leading positions.

In February 2015, the US President Barack Obama presented the new National Security Strategy to the Congress. This is his second and the last official and binding document that reflects the strategic vision of the democratic administration of the contemporary world order, the place and the role of the USA in it. Achievements of the democratic administration that were presented in it are positioned as a vector for further development of the USA. It is notable that the first Obama's National Security Strategy of 2010 corresponds much better to the changing in- 
ternational conditions than the new strategic vision of 2015. It is completely built on the concept, formulated in 2010, the key points of which have not undergone to significant changes. It was the concept of national renewal and the return of US global leadership. The strategy was aimed at constructing the foundations of American power and global influence. It is based on the idea of "reasonable force" represented by the Obama administration in 2009, which provided that the power and influence in the world begin from renewal inside the country. That's why Obama has placed into the foundation of national security strategy all the major social priorities of his presidency - a strong economy, affordable education and health, energy security, innovation [27].

In the National Security Strategy of 2015 the abovementioned idea of "inner power" as the ground for global influence was completely preserved. Moreover the leadership strategy implementation is completely moved from the National Security Strategy of 2010 as it has all the components of "smart power": a strong military, a strong economy, skilful diplomacy and universal values. The new strategy also provides the US orientation on joint action through partnership, coalitions and international organizations. The USA still reserves the right to unilateral use of force, but only in the case of imminent danger to its national security. The list of the major threats in general remained unchanged: nuclear weapons, climate changes and pandemics. The place of terrorism, that in 2010 was the main threat, took a broader concept - extremism. The threat of the spread and use of nuclear weapons is still on the first place [27].

Barack Obama's foreign policy strategy is very different from the strategy of global leadership of George. W. Bush Jr. and suggests carrying major efforts to restore the capacity of "moral leadership the US", the formation of pro-American world public opinion. The National Security Strategy of Barack Obama recognizes the value of partnership. It gives more importance to civil as opposed to military dimension and underlines the importance of dialogue and national need to strengthen international institutions. The strategy also highlights the political aspirations of the USA to support the formation of the international order that can solve the problems of international security for the sake of US global leadership. [28] Taking it all into consideration, changes in the forms and methods of implementation of American leadership were directed to eliminate imbalances that destabilize the international political system [29].

Conclusions. Nowadays, the US strategy of leadership is increasingly exposed to criticism. It is reported that attempts to unilaterally solve global military, economic, ideological and political problems turned to be the main reason of the US power "overloading" and led the US to the loss of their dominant role in the globalizing international system. Apart from the integration component, in the context of globalization, the disintegration vector that includes regionalization of world economy and politics became clearly apparent. There is a potential threat to the US leadership in the global economy. Before the third year of the war in Iraq, the status of world moral leader which came to the US after the collapse of the Soviet Union was finally lost. There was a need to formulate a new strategy for US global leadership. American political scientists have proposed a new vision of global leadership strategy: to proclaim a "polarless world" and haven taken under the control the key, from a resourceful and a strategic point of view, regions of the planet, in fact to regain leverage of the global governance. The spread of freedom and liberal democracy are declared to be the main goals. These concepts are approved by disappearance from the "Defensive strategy of the USA 2008", one of the major national strategies after 1991, thesis that in the USA in the nearest future there would be no global rivals.

\section{References}

1. Brzezinski Z. Three Presidents and the Crisis of American Superpower / Zbigniew Brzezinski. - New York : Basic Books, 2009. - 240 r. 
2. Hyland W. G. America's New Course / W. G. Hyland // Foreign Affairs. - Spring 1990. Vol. 69. - № 2. - P. 1-12.

3. Kagan R. The Benevolent Empire / R. Kagan // Foreign Policy. - №. 111, Summer 1998. 24-35.

4. Chwenninger Sh. Revamping American Grand Strategy / Sh. Schwenninger // World Policy Journal. - Fall 2003. - Vol. XX. - № 3. - P. 25-44.

5. White J. Still Seeing Red. How the Cold War Shapes the New American Politics / J. White. - Boulder (Co.), 1997. - 347 p.

6. Dudko I. D. Kriteriyi i mehanIzmi zabezpechennya mizhnarodno-politichnih Interesiv SShA v nestatsIonarnIy sistemi mizhnarodnih vidnosin : dis. d-ra polIt. nauk: 23.00.04 / Dudko Irina Dmitrivna ; Nats. akad. nauk UkraYini, In-t svIt. ekonomIki i mizhnar. vidnosin. - K., 2008. - $455 \mathrm{~s}$.

7. LakIshik D. M. Kontsept SShA v analitichnih doslidzhennyah suchasnih tendentsiy globalnogo rozvitku / D. M. LakIshik // Istoriko-politichni studiyi. Seriya : Politichni nauki : zb. nauk. pr. / M-vo osviti i nauki Ukrayini, DVNZ «KiYiv. nats. ekon. un-t Im. Vadima Getmana», In-t Istoriyi ukr. susp-va ; redkol. : I. D. Dudko (golova) [ta In.]. - Kyiv : KNEU, 2015. - № 2. - S. 56-65.

8. Ponomarov M. V. Istoriya krayin Evropi ta Ameriki v Novitniy chas. - M. : Prospekt. -416 c.

9. Rizhkov M. M. Strategiyi strimuvannya u zovnishniy ta bezpekoviy polititsi SShA/ M. M. Rizhkov // Aktualni problemi mizhnarodnih vidnosin. - 2011. - Vip. 102(1). - S. 5-21.

10. Fesenko M. V. Transformatsiya suchasnoyi sistemi mizhnarodnih vidnosin: kontseptualniy i prognostichniy vimir / M. V. Fesenko - K. : Tsentr vilnoyi presi, 2008. - $236 \mathrm{~s}$.

11. SShA i svit XXI stolittya : monograftya / Pahomov Yu. M., Koval I. M., Shergin S. O. ta inshi. - K. : Tsentr vilnoyi presi, 2013. - 620.

12. Yakovenko N., Piskorska G. Prioriteti mizhnarodno-politichnoyi diyalnosti CShA v strategiyah natsionalnoyi bezpeki / N. Yakovenko, G. Piskorska // Amerikanska Istoriya ta politika: naukoviy zhurnal. - № 2. - K., 2016. - 254 s.

13. Zhiltsov D. Evolyutsiya voenno-politicheskih vzglyadov SShA v period s nachala $90-\mathrm{h}$ godov po nastoyaschee vremya / D. Zhiltsov // Zarubezhnoe voennoe obozrenie №12, 2012. - C. 3-11.

14. Kabachenko A. P. Istoriya mirovoy politiki / A. P. Kabachenko. - M. : izdatelstvo MGU, 2007. $-828 \mathrm{c}$.

15. Mursalov R. S. Obsuzhdenie kontseptsii «soglasovannoy bezopasnosti» v pravyaschih krugah SShA (1993-1997 g.) / R. S. Mursalov // Vestnik Tomskogo gosudarstvennogo universiteta, 2013. - № 368. - S. 89-91.

16. Troitskiy M. A. Kontseptsiya «programmiruyuschego liderstva» v evroatlanticheskoy strategii SShA // Pro et Contra. - 2002. - № 4. - S. 86-103.

17. Torkunov A. V. Sovremennyie mezhdunarodnyie otnosheniya [Elektroniy resurs] / A. V. Torkunov / Uchebnik / Pod. red. A. V. Torkunova. - M. : «Rossiyskaya politicheskaya entsiklopediya» (ROSSPEN), 1999. - 584 s. - Rezhim dostupu: http://filosof.historic.ru/ books/item/f00/s01/z0001089/st000.shtml

18. Shakleina T. A. Rossiya i SShA v novom mirovom poryadke. Diskussii v politiko-akademicheskih soobschestvah Rossii i SShA (1991-2002) / T. A. Shakleina. - M. : Institut SShA i Kanadyi RAN, 2002. - 445 s.

19. Bzhezinskiy Z. Esche odin shans / Zbyignev Bzhezinskiy. Tri prezidenta i krizis amerikanskoy sverhderzhavyi. - M. : Mezhdunarodnyie otnosheniya, 2007. - 240 c. 
20. Zhiltsov D. Evolyutsiya voenno-politicheskih vzglyadov SShA v period s nachala 90-h godov po nastoyaschee vremya / D. Zhiltsov // Zarubezhnoe voennoe obozrenie. - № 12, 2012. - C. 3-11.

21. Shakleina T. A. Mirovoy poryadok v XXI veke. Evolyutsiya globalnoy strategii SShA (2001-2011) / T. A. Shakleina // Vestnik Moskovskogo Universiteta. Seriya : Mezhdunarodnyie otnosheniya i mirovaya politika. Seriya 25. - 2011. - № 3. - S. 35-58.

22. The National Security Strategy of the United States of America [Elektroniy resurs] - September, 2002. - Rezhim dostupu: http://wwwglobalsecurity.org/military/library/policy/national/nss-020920.pdf.

23. Podobinska-Shtik N. Protistoyannya bezpekovim zagrozam u SShA ta Velikiy Britaniyi : porIvnyalniy analiz [Elektroniy resurs] / N. PodobInska-Shtik // Viche. - № 6, berezen 2011. - Rezhim dostupu: http://www.viche.info/journal/2473.

24. Woodward B. Bush at War / B. Woodward. - New York : Simon and Shuster, 2002. - 376 p.

25. The National Security Strategy of the United States of America. - March, 2006.

26. National Strategy on Combating Terrorism. [Elektroniy resurs] / September, 2006. - Rezhim dostupu: http://www.fas.org/irp/threat/nsct2006.pdf.

27. Zhuravleva $V$. Yu. Evolyutsiya podhodov administratsii Obamyi k obespecheniyu natsionalnoy bezopasnosti [Elektroniy resurs] / V. Yu. Zhuravleva // Institut mirovoy ekonomiki i mezhdunarodnyih otnosheniy imeni E. M. Primakova. - 06. 04. 2015. - Rezhim dostupu: http://www.imemo.ru/index.php?page_id=502\&id=1602\&ret $=640$.

28. Shevchuk O. V. zovnishnopolitichni prioriteti administratsiyi B. Obami. / O. Shevchuk. // Naukovi pratsi [Chornomorskogo derzhavnogo universitetu Imeni Petra Mogili]. Ser. : Politologiya, 2013. T. 212, Vip. 200. - S. 9-13.

29. Matveeva O. PolItika globalnogo liderstva SShA za prezidenstva Baraka Obami / [Elektroniy resurs] O. Matveeva // Zovnishni spravi. - Ekspertna dumka. - 30. 04. 2015. Rezhim dostupu: http://uaforeignaffairs.com/ua/ekspertna-dumka/view/article/politika-globalnogo-liderstva-ssha-za-prezidenstva-ba/Hyland W. G. America's New Course / W. G. Hyland // Foreign Affairs. - Spring 1990. - Vol. 69. - № 2. - P. 1-12. 